\title{
A Comparison of English and Japanese Proverbs Using Natural Semantic Metalanguage
}
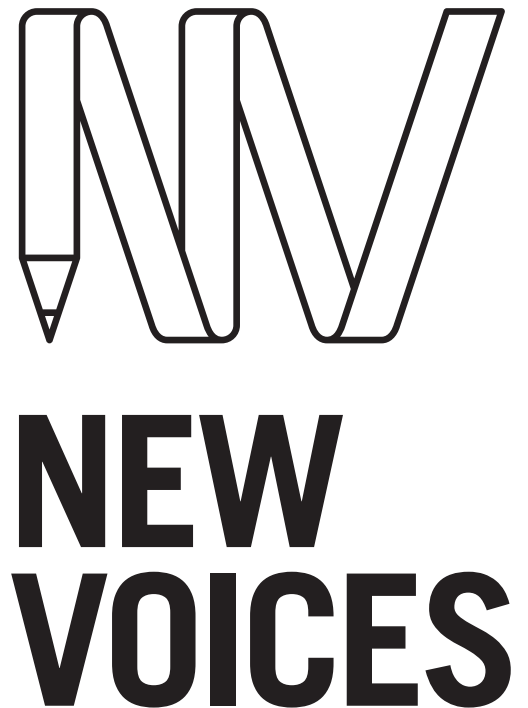

IN JAPANESE STUDIES

\section{MILES NEALE}

The University of Queensland

\section{ABSTRACT}

This investigation examines the meaning of semantically similar English and Japanese proverbs. It uses textual data sourced from online corpora to highlight and compare the different cultural and conceptual elements embedded within these proverbs. The findings of this investigation demonstrate that matching proverbs from different languages is a potentially problematic exercise, both in dictionaries and in the second-language classroom.

\section{KEYWORDS}

culture; linguistics; language; metaphor; Natural Semantic Metalanguage; proverb

\section{JAPANFOUNDATION 8 \\ BRINGING JAPAN TO YOU}

To link to this article:

http://dx.doi.org/10.21159/nvjs.07.05

\section{ISSN 2205-3166}

New Voices in Japanese Studies is an interdisciplinary, peer-reviewed journal showcasing the work of emerging scholars from Australia and New Zealand with research interests in Japan.

All articles can be downloaded free at newvoices.org.au

(c) The Japan Foundation, Sydney and Miles Neale, 2015

\section{(c) (i) $\odot$}




\section{INTRODUCTION}

This study compares two pairs of traditional English and Japanese proverbs that some Japanese dictionaries have identified as being similar in meaning. Its goals are to examine how these proverbs are used in everyday discourse and compare their meanings to test whether they are sufficiently similar to be paired together in dictionaries.

Japanese proverb dictionaries, such as the Shinmeikai koji kotowaza jiten (2007), the Kotowaza no izumi (Takashima 1981) and the Nichiei hikaku kotowaza jiten (Yamamoto 2007), offer English equivalents to the Japanese proverbs (called kotowaza) that they list. ${ }^{1}$ However, there are subtle differences between some of the proverbs that these dictionaries pair together. Take the Japanese proverb, 'Nen ni wa nen o ireyo (念には念を入れよ)', for example. The Shinmeikai dictionary offers 'Look before you leap' as an English equivalent (2007, 492). However, 'Nen ni wa nen o ireyo' directly translates as 'put care into care', ${ }^{2}$ which appears to have a slightly different meaning to that of 'Look before you leap'. In a semantic comparison of proverbs in different languages, Charteris-Black $(1995,263)$ recommends a "simple matching exercise", in which students match proverbs from one language with equivalent proverbs in another language, as a useful way of introducing different metaphorical lenses into second language studies. However, this study finds that not only the metaphors but also the meanings and usages of so-called equivalent Japanese and English proverbs are not identical, which casts doubt on the usefulness of this exercise for language learners.

Linguists such as Charteris-Black (1995; 1999) and Goddard (2009; 2013), anthropologists Obeng (1996) and Briggs (1985), and even psychologists (Brown and Lenneberg 1954) have compared traditional proverbs from different cultures. They have examined poetic language in depth, trying to gain an insight into how proverbs reflect cultural thought and behaviour. Proverbs attract attention in these scholarly fields because they reproduce the shared common knowledge of a culture, providing an insight into the values and beliefs of the people who use them. While researchers agree on the usefulness of proverbs as tools for examining shared cultural knowledge and culturally-specific language (Norrick 1985; Whaley 1993; Mieder 1985), some researchers disagree about what constitutes a proverb. In the context of this study, a proverb is defined as "a brief, decontextualised, selfcontained statement with a fixed form that conveys a sense of folk wisdom and traditionalism" (Norrick 1985, 31). This study is interested in comparing the folk wisdom and traditionalism contained within pairs of Japanese and English proverbs.

Proverbs convey folk wisdom using poetic devices such as metaphors. The different metaphors used in Japanese and English proverbs are an intriguing point of comparison, and a focus of this investigation. Lakoff and Johnson 
(1980) famously argued that "our conceptual system is largely metaphorical" and that "the way we think, what we experience, and what we do every day is very much a matter of metaphor" (124). Through language, cultures and societies share metaphors, and in so doing, share linguistic devices that structure how we view the world. By comparing Japanese and English metaphors, we are in effect comparing two societies' common knowledge and traditionally shared views on the world.

Just as there are similarities and differences between Japanese and Western culture, so too are there Japanese metaphors that share similarities with English metaphors and ones that do not. Thus, while some Japanese metaphors translate easily into English, others are not so compatible. As an example of this, Minami (2009) observes that English and Japanese share the metaphor of 'flowing water' to describe the progression of a story: "the flow of the story' in English and 'hanashi no nagare' in Japanese" (66). Conversely, the two languages also contain a number of metaphors that lose their meaning when directly translated into the other language. Minami uses the word 'parallel' as an example, explaining that you can use it to mean 'the same' in English (e.g. 'parallel interests'), but you cannot use the direct Japanese translation, 'heikō (平行)', in this way $(2009,57)$. Scholars have also observed that there are several words and concepts that cannot be directly translated across the two languages, such as the Japanese concept of 'amae (甘え)', which can be translated into English as 'spoiling', 'nestling up to', 'dependent upon' or even 'being fooled by', depending on the context in which the word is used (House 2000, 69).

Other commonly researched examples are metaphors that include the Japanese words 'kokoro (心)', meaning 'heart', and 'hara (腹)', meaning 'stomach' (see Hasada 2002, 108; Passin 1982, 87). Some Japanese expressions involving the word 'kokoro' are very similar to metaphorical English expressions featuring the word 'heart', such as 'kokoro ga kowareru (心が壊れる)', meaning 'one's heart breaks'. On the other hand, expressions like 'kokoro ga sawagu (心が騒 <゙)', meaning 'one's heart is troubled [lit., 'makes a lot of noise']', do not have similar English expressions. Furthermore, Japanese metaphors containing the word 'hara' express different concepts from English metaphors involving the stomach. For example, 'futoppara (太つ腹) [lit., 'large-stomached']' describes a person who is not necessarily rotund or gluttonous, but who is generous. This shows that words and metaphors in Japanese and English do not necessarily invoke similar imagery or have the same construction (Hasada 2002). Thus, we must employ a method of comparison that analyses the meaning of these metaphors, rather than one that looks solely at word-level differences.

\section{METHODOLOGY}

This study examines two pairs of 'equivalent' English and Japanese proverbs as defined by the Shinmeikai dictionary (2007), using Natural Semantic Metalanguage (NSM) to analyse the core meaning of each. Developed by linguists Anna Wierzbicka (1996) and Cliff Goddard (2002), NSM is a unique 
method of linguistic analysis that involves using simple words to express more complex meanings. This technique avoids the complex terminology and abbreviations that dictionaries are prone to use, and more importantly, provides a tool for expressing meaning that transcends culturally specific metaphorical language such as that found in proverbs. This study defines the complex concepts that English and Japanese proverbs express using a set of simple words called 'semantic primes', which Goddard calls "the irreducible semantic core of all natural languages" $(2002,8)$. These semantic primes are words that cannot be simplified further; some examples in English are 'I', 'you', 'someone', 'something', 'this', 'happen', 'know' and 'move'. Wierzbicka and Goddard use the term "reductive paraphrasing" (Goddard 2002, 7) to describe the process of using these words to express the meaning of a concept, and call the products of this process "semantic explications" (Wierzbicka 1996, 113). Semantic explications are made up of simple clauses constructed with semantic primes. By reducing proverbs to NSM semantic explications, we can express and compare their meanings using the same universal terminology.

This study departs from dictionary definitions and instead offers new NSM definitions of Japanese and English proverbs. Simply paraphrasing the meaning of proverbs based on an individual source could lead to error, bias or a reliance on the dictionary definitions being scrutinised. Therefore, this study examines how various members of the public interpret the meaning of specific proverbs by randomly sampling texts from the British National Corpus (BNC) and the Balanced Corpus of Contemporary Written Japanese (BCCWJ) which contain the chosen English and Japanese proverbs. ${ }^{3}$ The BNC is a 100-million-word collection of samples from a wide range of written and spoken sources. It is a representative cross-section of British English usage from the later part of the 20th century, and thus is an authoritative corpus from which to sample everyday discourse incorporating proverbs. Similarly, the BCCWJ is a corpus of 100 million words of contemporary written Japanese sourced from publications, government documents and text from the internet. Its comprehensiveness makes it the most valid corpus from which to source discourse incorporating Japanese proverbs. Following analysis of corpus data, this study creates and compares NSM semantic explications of the proverbs, identifying differences in their meaning and construction. It uses textual data from the corpora to determine how people link proverbs to real life events, and identifies how Japanese and Western common knowledge is reproduced in these proverbs.

The semantic explications are based on a five-part semantic template for proverbs that was originally developed by Goddard (2009). The five sections in this template describe what Goddard sees as the core characteristics of proverbs: 'traditionality', a 'recurrent situation', 'advice', 'analogy' and 'status as folk wisdom'. Goddard notes that 'traditionality' and 'status as folk wisdom' are qualities that all proverbs share $(2002,107)$. 'Traditionality' describes how users position a proverb as something that people have used over a long period of time, while 'status as folk wisdom' describes how a proverb communicates the common knowledge of a specific culture. As these qualities are common

3 The British National Corpus (BNC) is managed by Oxford University Computing Services on behalf of the BNC Consortium. The Balanced Corpus of Contemporary Written Japanese (BCCWJ) is produced by the 
to all proverbs and therefore are not useful for distinguishing differences, they are omitted from the explications in this study.

The focus herein is on the other three sections of Goddard's template, which examine the content of proverbs. The first element, [a] recurrent situation, describes the real-life situation that a proverb warns against. For example, the recurrent situation of 'A bird in the hand is worth two in the bush' is that people are prone to pursue things of great value that they do not have, rather than hold onto things of lesser value that they do have. The second, [b] advice, describes the moral lesson of a proverb. The advice of 'The early bird catches the worm', for example, is that one should wake up early. It should be noted that some metaphorical proverbs, such as 'Out of the frying pan and into the fire', lack the advice element. The final element, [c] analogy, describes the metaphor contained in a proverb and what it stands for. In 'A stitch in time saves nine', stitching up tears before they widen is an analogy for acting to solve a minor problem before it becomes a major problem. It is important to note that non-metaphorical, maxim-style proverbs, such as 'Respect your elders', do not employ an analogy. In this section of the template, the metaphors within proverbs will be paraphrased so that they can be easily compared.

In addition, these metaphors are examined from a cognitive linguistic perspective, identifying the image schema and conceptual metaphors that underpin them. An image schema is a fundamental, recurring pattern of cognition that we use subconsciously to represent and understand complex concepts (Johnson 1987, 23). An example is the 'containment' schema, which is observable in phrases where the human body is metaphorically portrayed as a container for emotions, such as 'I bottled up my anger'. Image schemas are present in the metaphors employed in English and Japanese proverbs, and are an interesting point of difference between the two. They will thus be examined herein.

The proverbs that are the subject of this study are two commonly-used English proverbs and their Japanese equivalents. The English proverbs being examined have been chosen because the Shinmeikai dictionary links them with well-known Japanese proverbs, and because they are commonly used in their own right. These proverbs are 'Look before you leap' and 'The proof of the pudding is in the eating'. Their Japanese pairs in the Shinmeikai dictionary are proverbs from the popular Edo version of the iroha karuta card game: 'Nen ni wa nen o ireyo' $(2007,492)$ and 'Ron yori shōko (論より証拠)' $(672) .{ }^{4}$

\section{ANALYSIS: 'LOOK BEFORE YOU LEAP’ AND ‘NEN NI WA NEN O IREYO’}

\section{Proverb 1: Look before you leap}

The first step in comparing these proverbs is to examine samples of texts in which they are used. This gives an insight into how the proverbs are employed 
in everyday discourse and assists with comparing and re-evaluating their definitions. We begin by analysing the following excerpts of texts, retrieved from the BNC, containing the English proverb 'Look before you leap':

\section{Text 1.1}

'Look before you leap' is a maxim impulsive people fail to follow. People who aren't impulsive think through the consequences of their actions before taking decisive steps. They can resist temptation long enough to make decisions based on good sense. Impulsive people are just the opposite. They do things rashly. They make snap decisions. They lack self-control... [ARJ] $]^{5}$

\section{Text 1.2}

You yearn to bring about a revolution in your lifestyle and it's undoubtedly possible in April-but it will be a hollow victory if you overthrow one repressive regime just to replace it with another. Proceed with caution and, at the risk of sounding like a tabloid astrologer, look before you leap. [ECT]

\section{Text 1.3}

There are many old sayings and proverbs that point to the wisdom of thought before action, such as 'look before you leap', 'more haste, less speed', 'second thoughts are best', and so on. If you are able to prevent the things you have been doing, then you are already half-way to your goal. [BM0]

(BNC 2007)

The Oxford British and World English Dictionaries both explain the meaning of 'Look before you leap' as "You shouldn't act without first considering the possible consequences or dangers" (Oxford Dictionaries 2015a). Similarly, these three texts explain 'Look before you leap' as an admonition to think before acting. With the metaphor of leaping comes the implication that the actor to whom the proverb is referring is attempting to achieve a goal. These texts present hypothetical actors with two potential scenarios: in the first one, the actor acts without thinking and meets with failure. This scenario, although implicitly present in each text, is most clearly described by Text 1.1, which says that "Impulsive people...do things rashly. They make snap decisions. They lack self-control". This line is representative of the 'recurrent situation' of the proverb; that is, it paraphrases the proverb's warning about what often happens to people who have not learned from its moral tale. The recurrent situation in 'Look before you leap' can be rendered in NSM as below:

\section{[a] Recurrent situation}

something like this often happens:

someone does something because this someone wants something to happen before this someone does it, this someone doesn't think about it because of this, when this someone does it, something bad happens to this someone

The texts indicate that the alternative scenario for the actor is to be cautious and, as Text 1.1 states, "think through the consequences of their actions before taking decisive steps". This is the moral, or 'advice', of this proverb. It can be rephrased in NSM as follows: 


\section{[b] Advice}

when someone does something because this someone wants something to happen

it is good if this someone thinks about it before this someone does it

This proverb's analogy can also be deduced from the above texts. Text 1.3 says that the proverb advocates "the wisdom of thought before action". Within the proverb, 'looking' represents thinking ahead and preparing for one's next move, while 'leaping' represents stepping out and taking action. We can represent these metaphorical analogies in NSM as such:

\section{[c] Analogy}

it is often like this:

\begin{abstract}
someone moves because this someone wants to be somewhere this someone doesn't see this place before this someone moves, this someone doesn't know anything about this place a bad thing will happen when this someone moves
\end{abstract}

The main metaphors within this proverb, 'looking' and 'leaping', can also be defined using image schemas. The analogy of leaping from one area to another area reflects the 'source-path-goal' schema and the conceptual domain of a 'journey'. In addition, 'looking', a metaphor that represents 'caution' and 'preparation', aligns with the 'physical perception' and 'visual perception' schema (Faber 1999, 258). These image schemas influence the terminology that texts use. This is particularly evident Text 1.3, which echoes the 'sourcepath-goal' schema and the 'journey' domain when it states that following the advice of the proverbs puts you "halfway towards your goal". Text 1.2 also reproduces this image schema with the advice to readers to "proceed with caution". It appears then that the image schemas and conceptual domains that feature in this proverb influenced word choice and how the proverb was positioned in the texts.

\section{Proverb 2: Nen ni wa nen o ireyo (lit., 'put care into care')}

Having identified the basic meaning of 'Look before you leap' and some of its underlying conceptual metaphors, this study will now examine the Japanese proverb listed as the equivalent to 'Look before you leap' by the Shinmeikai dictionary: 'Nen ni wa nen o ireyo' $(2007,492)$.

$\begin{array}{lllll}\text { Nen } & \text { niwa } & \text { nen } & \text { o } & \text { ireyo } \\ \text { care } & \text { TOP } & \text { care } & \text { ACC } & \text { put in-IMP (archaic) }\end{array}$

The following are texts from the BCCWJ that contain 'Nen ni wa nen o ireyo'.

\section{Text 2.1}

When flying a foreign flag, remember the lesson taught by 'Nen ni wa nen o ireyo' and be sure not to fly the wrong flag or fly it upside-down. ${ }^{6}$

6 「外国旗を掲揚するときは、旗の間違いや上下逆さまのミスを起こしやすいので、念には念を入れよという教 


\section{Text 2.2}

No matter how much you know or how thoroughly you have prepared, when it comes to moving, the unexpected often happens. I strongly felt that it was necessary to 'Nen ni wa nen o ire' and have someone talk with the removalists for me and help me out with other odd jobs.?

\section{Text 2.3}

Even though I knew there was no one there, I 'Nen ni wa nen o irete' and trod lightly. I gently twisted the doorknob so that it wouldn't make a noise.

(BCCWJ 2009) ${ }^{8}$

The content of these sample texts is indeed similar to the texts containing 'Look before you leap'. Texts in both sets appear to use the proverb to advocate caution rather than rash action. However, there are subtle differences between the two proverbs that become apparent when the texts are examined in detail. Let us first look at the recurrent situation described by 'Nen ni wa nen o ireyo'.

Text 2.1 perhaps provides the best indication of this proverb's 'recurrent situation' (the undesirable outcome of not following the advice of the proverb). This text uses the proverb to warn people who fly national flags to be especially careful, lest they fly a flag upside-down or fly an incorrect flag. While this echoes the warning expressed in 'Look before you leap' (i.e., that rash action leads to disaster), the tone of Text 2.1 is different from the tone of the English texts. This difference is made clearer by Text 2.2 , in which the narrator reflects on their experience of moving house in old age. Text 2.2 advises other elderly house-movers to be cautious, but also assumes that they have already taken certain precautions. It says that these people should be cautious "no matter how much you know or how much you have prepared". This statement and the literal meaning of the proverb ('put care into care') imply that people will think about their problem ahead of time, but advises those people to think about that problem more carefully. This situation contradicts the situation of 'Look before you leap', which describes the actor not thinking at all before they act. The texts' usage of the proverb reflect the Shinmeikai dictionary's Japanese definition of 'Nen ni wa nen o ireyo': "after you have been cautious and checked, be even more cautious (よく注意し確かめたうえに、さらに注意せ よ)" (2007, 492). We must portray this aspect when explicating the recurrent situation of 'Nen ni wa nen o ireyo' to reflect that of the above texts:

\section{[a] Recurrent situation}

something like this often happens:

someone does something because this someone wants something to happen before this someone does it, this someone thinks about it after this, this someone doesn't think about it anymore something bad happens because of this

Text 2.3 describes a person who is trying not to be heard. It implies that if this person is heard, something bad could happen to them. To avoid this, the 
person heeds the advice of 'Nen ni wa nen o ireyo' and thinks carefully about his or her actions. This sentiment, which is the advice of the Japanese proverb,

is echoed in Texts 2.1 and 2.2. We can rewrite this advice in NSM as follows:

\section{[b] Advice}

when someone does something because this someone wants something to happen

it is good if this someone thinks about it well

The final element of Goddard's semantic template is the 'analogy'. However, 'Nen ni wa nen o ireyo' is a literal maxim that does not employ an analogy. This section must therefore be omitted from the NSM explication. Considering this proverb does not contain an analogy, it can be concluded that users were not influenced by a specific conceptual metaphor. This is another aspect that sets 'Nen ni wa nen o ireyo' apart from 'Look before you leap'.

Table 1: NSM explications of 'Look before you leap' versus 'Nen ni wa nen o ireyo'

\begin{tabular}{|c|c|}
\hline Look before you leap & Nen ni wa nen o ireyo \\
\hline $\begin{array}{l}\text { [a] Recurrent situation } \\
\text { something like this often happens: } \\
\text { someone does something because this someone wants } \\
\text { something to happen } \\
\text { before this someone does it, this someone doesn't think about it } \\
\text { because of this, when this someone does it, } \\
\text { something bad happens to this someone }\end{array}$ & $\begin{array}{l}\text { [a] Recurrent situation } \\
\text { something like this often happens: } \\
\text { someone does something because this someone wants } \\
\text { something to happen } \\
\text { before this someone does it, this someone thinks about it } \\
\text { after this, this someone doesn't think about it anymore } \\
\text { something bad happens because of this }\end{array}$ \\
\hline $\begin{array}{l}\text { [b] Advice } \\
\text { when someone does something because this someone wants } \\
\text { something to happen } \\
\text { it is good if this someone thinks about it before this someone does it }\end{array}$ & $\begin{array}{l}\text { [b] Advice } \\
\text { when someone does something because this someone wants } \\
\text { something to happen } \\
\text { it is good if this someone thinks about it well }\end{array}$ \\
\hline $\begin{array}{l}\text { [c] Analogy } \\
\text { it is often like this: } \\
\text { someone moves because this someone wants to be somewhere } \\
\text { this someone doesn't see this place before this someone moves, } \\
\text { this someone doesn't know anything about this place } \\
\text { a bad thing will happen when this someone moves }\end{array}$ & $\begin{array}{l}\text { [c] Analogy } \\
\text { N/A }\end{array}$ \\
\hline
\end{tabular}

Table 1 aligns and compares complete NSM explications of the English proverb and its corresponding Japanese proverb. Comparing the two explications in this manner, it becomes clear that while the meanings of the two proverbs are indeed similar, they differ in subtle ways. 'Look before you leap' describes a recurrent situation where a person acts without thinking, and 'Nen ni wa nen $o$ ireyo' describes a person who has prepared for something to a certain extent but should prepare even more. This difference is also reflected in the advice of the proverbs. The analogy of 'Look before you leap' employs two image schemas: 'source-path-goal' and 'visual perception'. These image schemas are evidence of conceptual domains that users reproduce when positioning the proverb in discourse (for example, Texts 1.2 and 1.3 use the proverb to talk about achieving a goal). Meanwhile, 'Nen ni wa nen o ireyo' does not employ an analogy, and thus its sample texts did not contain phrases sourced from 
those same conceptual domains. As we saw in examples from the BNC, texts are likely to use 'Look before you leap' in relation to 'movement' (Text 1.1 refers to "taking decisive steps", for example). In contrast, 'Nen ni wa nen o ireyo' contains no analogies that influence how it is used in discourse.

The similarities of these two proverbs may explain the decision of proverb dictionaries like the Shinmeikai to pair them together. However, NSM analysis has demonstrated that the two proverbs have subtly different meanings, and translators should be warned against simply substituting one for the other.

Do other proverb pairs have similar semantic and pragmatic differences? This study now investigates the proverb, 'The proof of the pudding is in the eating' and its Japanese pair according to the Shinmeikai dictionary: 'Ron yori shōko' $(2007,672)$.

\section{ANALYSIS: 'THE PROOF OF THE PUDDING IS IN THE EATING' AND 'RON YORI SHŌKO'}

\section{Proverb 3: The proof of the pudding is in the eating}

This section examines three randomly selected texts from the BNC containing the Shinmeikai dictionary's English equivalent to 'Ron yori shōko': 'The proof of the pudding is in the eating'.

\section{Text 3.1}

We might reply that the simplicity of cave communities is idiosyncratic rather than typical: we might ask what general ecological insights we are going to obtain from communities that lack photosynthetic plants and herbivores, and are maintained by detritus flushed down from above: but Dr Culver gives us no answer. Arguments of this kind are easy to invent, but difficult to settle: in the end, the proof of the pudding will be in the eating. So let us turn to the main part of Culver's book, and see whether his hopes are substantiated. Has, in fact, the study of cave life settled any important questions in evolution or ecology... [B7L]

\section{Text 3.2}

Working on the principle that half a loaf is better than none, the British side accepted the agreement, intending to open negotiations separately on military issues. The modus vivendi was not signed, but it was promulgated in January 1948 in the minutes of the Combined Policy Committee so as to avoid reference to Congress or to the United Nations, which would have been necessary for a formal international agreement. The proof of the pudding was in the eating: the modus vivendi turned out to be a great disappointment. The Americans got their ore, but the British received a pittance of information in return... [ABA]

\section{Text 3.3}

There's no install program; you just copy the files across to the hard disk. Similarly, while a front-end [interface] is available, the program is designed to be run from the command line, like good old PKZIP. Mercifully, the Windows

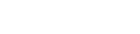

(n)


shell offers you tick boxes instead of command line switches to make life a little easier. The proof of the pudding is in the eating and while I found that [the anti-virus software] didn't quite live up to the advertisers' claims, it was able to spot over 84 per cent of the infected files in my library... [FT8]

(BNC 2007)

The three sample texts demonstrate that "The proof of the pudding is in the eating' is used when referring to the process of testing something to find out more about its value. This reflects the Oxford British and World English Online Dictionaries' definition of the proverb: "The real value of something can be judged only from practical experience or results and not from appearance or theory" (Oxford Dictionaries 2015b). However, this definition simply summarises the advice of the proverb and does not touch on the proverb's recurrent situation. The alternative to following the advice of the proverb is described well by Text 3.2, which says "The proof of the pudding was in the eating: the modus vivendi turned out to be a great disappointment". The text here is saying that because British diplomats put their faith in a trade deal that wasn't guaranteed to be beneficial, they were left with an unfavourable deal. Meanwhile, Text 3.1 warns about the dangers of presenting arguments without supporting them with evidence, and Text 3.3 implies that readers would not have known about the value of a brand of anti-virus software if it had not been tested. We can deduce from this that the 'test' involved in 'The proof of the pudding is in the eating' can refer to a range of different objects and ideas. This should be taken into account when representing the recurrent situation of this proverb in NSM:

\section{[a] Recurrent situation}

something like this often happens:

a person thinks like this:

I know about a thing

because of this, this person does not do something

because of this, this person does not know this thing

something bad can happen to this person because of this

How should we interpret the advice offered by this proverb? Unlike 'Look before you leap', it is not immediately clear from the text samples how 'The proof of the pudding' is used to offer advice. In Text 3.1, the proverb is used to argue that the theories of a scientist (a "Dr Culver") should be proven by examining "the main part of his book" before they are believed. Text 3.2 uses the proverb to explain that a modus vivendi between British and US diplomats was believed to be better than it turned out to be in practice. Conversely, Text 3.3 uses the proverb to argue that testing antivirus software is a worthwhile endeavour. The implied advice of the proverb in these three texts is that 'it is good to test an unknown thing and learn more about it'. This can be expressed in NSM in the following manner:

\section{[b] Advice}

because of this, it is good if a person thinks like this:

I do not know this thing

I want to know about this thing 
The analogy of 'The proof of the pudding is in the eating' is difficult to paraphrase in NSM, as the semantic primes are not capable of adequately describing food. However, Wierzbicka (2001) and Goddard (2002) propose that certain semantic units, called 'semantic molecules', can be used to express complex concepts that cannot be explained using semantic primes. Goddard defines the verb "to eat", for example, as a semantic molecule $(2010,469)$. Using semantic molecules (labelled using the [m] symbol), we can produce an intelligible NSM definition of this proverb's analogy. The noun 'pudding', while not a semantic prime or molecule, is used to make the explication clearer:

\section{[c] Analogy}

it is often like this:

someone makes $[\mathrm{m}]$ something for people to eat [m], like a ${ }^{*}$ pudding this someone thinks like this about it:

"maybe this is very good (to eat), maybe it is not good, I

don't know"

because of this, this someone eats some of it

after this, this someone knows, he/she can't not know

this someone can't know if this someone doesn't eat some of it

\section{Proverb 4: Ron yori shōko (lit., 'argument less than proof/ demonstration')}

Directly translating the Japanese proverb 'Ron yori shōko' demonstrates that its analogy differs from that of 'The proof of the pudding is in the eating'.

\begin{tabular}{|lll|}
\hline $\begin{array}{l}\text { Ron } \\
\text { argument }\end{array}$ & yori & shōko \\
less than & proof/demonstration \\
\hline
\end{tabular}

While the English proverb uses an analogy, 'Ron yori shōko' simply offers literal advice. Does this difference lead to differing interpretations of the proverb's meaning? This is now tested by investigating texts from the BCCWJ.

\footnotetext{
Text 4.1

"Sensei, I want to see!" Everyone said "I want to see!" In the end, Ron yori shōko. I pick up the fairy light, and break just the glass. ${ }^{9}$

\section{Text 4.2}

If you just focus on one case and don't consider other points of comparison or examples, you can't really call it an objective evaluation. Ron yori shōko, I will look at other examples. I will [look into] one part of "Research into the invasion of East Asia"... ${ }^{10}$
} 
Text 4.3

I stuck something like a Salon Pass [muscle relaxant patch] on the arch of my foot and it really worked well. Ron yori shōko, give it a try first.

(BCCWJ 2009)11

It is clear that these three texts use 'Ron yori shōko' to make a comparison between a theory (or an argument) and a proof (or a demonstration). In Text 4.1, the teacher is arguing that it is better to demonstrate a theory through an experiment rather than simply explaining that theory. Text 4.2 makes an argument about the value of investigating something thoroughly, but then states that it is better to demonstrate this value than just talk about it. Meanwhile, Text 4.3's claim is about the quality of muscle relaxant patches, while its proof will be the result of the reader's test of those patches. Note here that while 'The proof of the pudding is in the eating' could refer to a test of an actual thing (such as the anti-virus software in Text 3.3), the three Japanese texts are all testing metaphysical things, such as arguments and theories.

Table 2: NSM explications of 'The proof of the pudding is in the eating' versus 'Ron yori shōko'

\begin{tabular}{|c|c|}
\hline The proof of the pudding is in the eating & Ron yori shōko \\
\hline $\begin{array}{l}\text { [a] Recurrent situation } \\
\text { something like this often happens: } \\
\text { a person thinks like this: } \\
\qquad \text { I know about a thing } \\
\text { because of this, this person does not do something } \\
\text { because of this, this person does not know this thing } \\
\text { something bad can happen to this person because of this }\end{array}$ & $\begin{array}{l}\text { [a] Recurrent situation } \\
\text { something like this often happens: } \\
\text { some people say about something: "it is like this, people } \\
\text { can know it" } \\
\text { someone thinks about it like this because of this: } \\
\text { "now I know it, it is like these people say" } \\
\text { this is bad }\end{array}$ \\
\hline $\begin{array}{l}\text { [b] Advice } \\
\text { because of this, it is good if a person thinks like this: } \\
\text { I do not know this thing } \\
\text { I want to know about this thing } \\
\text { because of this, I will do something to this thing } \\
\text { if I do this, I will know this thing }\end{array}$ & $\begin{array}{l}\text { [b] Advice } \\
\text { if some people say about something: "it is like this, people can } \\
\text { know it" } \\
\text { it is not good if someone thinks because of this: } \\
\text { "now I know it, it is like these people say" } \\
\text { it is good if someone thinks like this: } \\
\text { "maybe it is like this, maybe it is not like this, I don't know } \\
\text { if I do something because of this, I can know" }\end{array}$ \\
\hline $\begin{array}{l}\text { [c] Analogy } \\
\text { it is often like this: } \\
\text { someone makes [m] something for people to eat [m], like a } \\
\text { *pudding } \\
\text { this someone thinks like this about it: } \\
\text { "maybe this is very good (to eat), } \\
\text { maybe it is not good, I don't know" } \\
\text { because of this, this someone eats some of it after this, this } \\
\text { someone knows, he/she can't not know } \\
\text { this someone can't know if this someone doesn't eat some of it }\end{array}$ & $\begin{array}{l}\text { [c] Analogy } \\
\text { N/A }\end{array}$ \\
\hline
\end{tabular}

The Shinmeikai dictionary's definition of 'Ron yori shōko' is "Things will become clearer if you show evidence/proof rather than making empty arguments（口先の議論を重ねるよりも、証拠を出したほうが物事が明らかにな る)" (2007, 672). Again, this is a good summary of the advice of the proverb, but it does not describe the recurrent situation. This can, however, be defined 
by looking to the texts. The recurrent situation of this proverb is made clear by Text 4.1, which states that a demonstration is better than simply explaining an experiment, which might cause the teacher's students to lose interest. The texts all warn that it is not good for someone to just talk about something, and for others to simply believe those arguments. We can articulate this message in NSM like this:

\section{[a] Recurrent situation}

something like this often happens:

some people say about something: "it is like this, people can

know it"

someone thinks about it like this because of this:

"now I know it, it is like these people say"

this is bad

Texts 4.2 and 4.3 both advise readers that their own claims are not as useful as tests of those claims. For example, Text 4.3 says that rather than simply making claims about a muscle relaxant patch, it is best to try and see for yourself whether it works. In other words, according to the sample texts, the proverb's advice is that it is better to find proof or present a demonstration rather than to make arguments. This is subtly different to the advice of 'The proof of the pudding is in the eating', which specifically argues the value of testing physical and metaphysical things. The following NSM explication of the Japanese proverb's advice expresses this subtle difference:

\section{[b] Advice}

if some people say about something: "it is like this, people can know it" it is not good if someone thinks because of this:

"now I know it, it is like these people say"

it is good if someone thinks like this:

"maybe it is like this, maybe it is not like this, I don't know

if I do something because of this, I can know"

Where 'Ron yori shōko' differs from 'The proof of the pudding is in the eating' is that while 'The proof of the pudding is in the eating' uses a metaphor to communicate its advice, 'Ron yori shōko' is a simple comparative maxim that does not employ any metaphors or analogies. The absence of an analogy in 'Ron yori shōko' means that users are unlikely to make links with a specific conceptual domain. This is why no patterns were found in the kinds of phrases used in the texts, or in the context in which the proverb was positioned. This contrasts with the metaphor found in 'The proof of the pudding is in the eating', which, as evidence from the sample texts shows, compels people to use the proverb in discourse relating to food.

Table 2 demonstrates that whilst 'Ron yori shōko' and 'The proof of the pudding is in the eating' have very similar meanings, they differ both in their analogies and in what they advise people to test. 'The proof of the pudding is in the eating' tells people to test the validity of things in general, and 'Ron yori shōko' warns people to test the truth of an argument. This is another example of a Japanese proverb with a similar but subtly different meaning from that of its English proverb pair. 


\section{CONCLUSION}

This study has shown that two English and Japanese proverbs paired together by the Shinmeikai dictionary in fact have a number of subtle differences. These differences emerged in the proverbs' culturally oriented advice, warnings and analogies (or lack thereof), and in the conceptual metaphors and image schemas through which these analogies were created. Because of these differences, the proverbs were used differently in sample texts. This should serve as a warning that so-called equivalent proverbs are rarely used in exactly the same way. These results indicate that it would be worthwhile examining other Japanese and English proverb pairs, as their meanings may also differ. The results of this study also cast doubt on Charteris-Black's $(1995,263)$ claim that a "simple matching exercise" in which students match a certain language's proverbs with equivalent proverbs in another language would be a useful way of introducing different metaphorical lenses into second language studies. While this activity would help learners to recognise the different metaphors that exist in different cultures, the activity's implication that one language's proverb is 'equivalent' to that of another language is potentially problematic, as the semantic explications in this investigation have shown. To better understand another culture's proverbs and how they are used in discourse, precise tools for analysing their meaning, such as NSM semantic explications, are useful (Goddard 2013).

The explications in this study revealed more about the different cultural and ideological knowledge embedded within proverbs than the aforementioned proverb dictionaries' definitions did. These dictionaries would do well to either offer similar explanations of the semantic differences between the Japanese and English proverbs that they link, or avoid the practice of linking proverbs altogether.

\section{GLOSSARY}

$\begin{array}{ll}\text { ACC } & \text { Accusative } \\ \text { BCCWJ } & \text { Balanced Corpus of Contemporary Written Japanese } \\ \text { BNC } & \text { British National Corpus } \\ \text { DAT } & \text { Dative } \\ \text { IMP } & \text { Imperative } \\ \text { NSM } & \text { Natural Semantic Metalanguage } \\ \text { TOP } & \text { Topic }\end{array}$

\section{REFERENCES}

BCCWJ (Balanced Corpus of Contemporary Written Japanese) [現代日本語書き言葉 均衡コーパス]. 2009. Distributed by the National Institute for Japanese Language and Linguistics. Accessed 14 November, 2014. http://www.ninjal.ac.jp/corpus_ center/kotonoha.html.

Briggs, C. L. 1985. "The Pragmatics of Proverb Performances in New Mexican Spanish.” American Anthropologist 87 (4): 793-810. 
BNC (The British National Corpus), version 3 (XML Edition). 2007. Distributed by Oxford University Computing Services on behalf of the BNC Consortium. Accessed 14 November, 2014. http://www.natcorp.ox.ac.uk/.

Brown, R. and Lenneberg, E. 1954. "A Study in Language and Cognition." The Journal of Abnormal and Social Psychology 49 (3): 454.

Charteris-Black, J. 1995. "Proverbs in Communication." Journal of Multilingual and Multicultural Development 16 (4): 259-68.

1999. "The Survival of English Proverbs: A Corpus Based Account." De Proverbio 5 (2). Accessed 2 November, 2014. http://www.deproverbio.com/display. php?a $=3 \& \mathrm{r}=96$.

Faber, P. B. and Usón, R. M. 1999. Constructing a Lexicon of English Verbs. New York: Walter De Gruyter.

Goddard, C. 2002. "The Search for the Shared Semantic Core of All Languages." In Meaning and Universal Grammar: Theory and Empirical Findings, edited by C. Goddard and A. Wierzbicka, 5-40. Amsterdam: John Benjamins.

2009. "Like a Crab Teaching Its Young to Walk Straight: Proverbs, Semantics, and Indexicality in English and Malay." In Ritual Communication, edited by G. Senft and Ellen B. Basso, 103-25. New York: Berg.

2010. “The Natural Semantic Metalanguage Approach." In The Oxford Handbook of Linguistic Analysis, edited by B. Heine and H. Narrog, 459-84. Oxford: Oxford University Press.

2013. "A Stitch in Time and the Way of the Rice Plant: The Semantics of Proverbs in English and Malay." In Words and Meanings: Lexical Semantics across Domains, Languages, and Cultures, edited by C. Goddard and A. Wierzbicka, 33661. Oxford: Oxford University Press.

Hasada, R. 2002. "Body Part' Terms and Emotions in Japanese." Pragmatics and Cognition 10: 107-28.

House, J. 2000. "Linguistic Relativity and Translation.” In Explorations in Linguistic Relativity, edited by M. Pütz and M. Verspoor, 69-88. Amsterdam: John Benjamins.

Johnson, M. 1987. The Body in the Mind: The Bodily Basis of Meaning, Imagination, and Reason. Illinois: University of Chicago Press.

Lakoff, G., and Johnson, M. 1980. Metaphors We Live By. Chicago: University of Chicago Press.

Mieder, W. 1985. "Popular Views of the Proverb." Proverbium 2: 109-43.

Minami, M. [南 雅彦]. 2009. Gengo to bunka [言語と文化]. Tokyo: Kuroshio [くろしお].

Norrick, N. 1985. How Proverbs Mean: Semantic Studies in English Proverbs. Berlin:

Walter de Gruyter. 
Obeng, S. G. 1996. "The Proverb as a Mitigating and Politeness Strategy in Akan

Discourse.” Anthropological Linguistics 38 (3): 521-49.

Oxford Dictionaries. 2015a. "Look Before You Leap." Oxford University Press. Accessed 28 March, 2015. http://www.oxforddictionaries.com/definition/english/ look-before-you-leap.

Oxford Dictionaries. 2015b. "The Proof of the Pudding Is in the Eating." Oxford University Press. Accessed 28 March, 2015. http://www.oxforddictionaries.com/ definition/english/the-proof-of-the-pudding-is-in-the-eating.

Passin, H. 1982. Encounters with Japan. Tokyo and New York: Kodansha International Ltd.

Shinmeikai koji kotowaza jiten [新明解故事ことわざ辞典]. 2007. Tokyo: Sanseidō [三 省堂].

Takashima, T. [高嶋 泰二]. 1981. Kotowaza no izumi: Nichi ei doku futsu taishō kotowaza jiten [日・英独仏対照彥辞典]. Tokyo: Hokuseido shoten [北星堂書店].

Whaley, B. B. 1993. “When 'Try, Try Again' Turns to 'You're Beating a Dead Horse': The Rhetorical Characteristics of Proverbs and their Potential for Influencing Therapeutic Change." Metaphor and Symbolic Activity 8 (2): 127-39.

Wierzbicka, A. 2001. "A Culturally Salient Polish Emotion: Pryzykro." In Emotions in Crosslinguistic Perspective, edited by J. Harkins and A. Wierzbicka, 337-58. Berlin: De Gruyter Mouton.

1996. Semantics: Primes and Universals. Oxford: Oxford University Press.

Yamamoto, T. [山本 忠尚]. 2007. Nichiei hikaku kotowaza jiten [日英比較ことわざ 辞典]. Tokyo: Sōgensha henshūbu [創元社編集部]. 